\title{
Leptoxyphium kurandae - New record of insect gut associated sooty mould fungus from India
}

\author{
Kajale SC, Sonawane MS, Sharma R and Shouche YS
}

Microbial Culture Collection, National Centre for Cell Science, NCCS Complex, Ganeshkhind, Pune-411 007 (Maharashtra), India

Kajale SC, Sonawane MS, Sharma R, Shouche YS 2015 - Leptoxyphium kurandae - New record of insect gut associated sooty mould fungus from India. Mycosphere 6(2), 133-138, Doi $10.5943 /$ mycosphere/6/2/2

\begin{abstract}
During a survey to study insect associated fungi, a sooty mould fungus, Leptoxyphium kurandae found in a gut of insect (Dusky Cotton bug) from Western Ghats, Junnar, India was isolated. It is characterized by elongated synnemata consisting of hyphae with bulbous base and at apex an open terminal funnel shaped conidiogenous zone. The hyphae composed of cylindrical cells, constricted at septa and covered with thick mucilaginous layer. Based on morphological characters and sequence comparison of the internal transcribed spacer (ITS) of rDNA and large subunit of ribosome (LSU), the fungus was identified as Leptoxyphium kurandae, a species not previously known from India.
\end{abstract}

Key words - Dusky cotton bug - ITS - LSU - Synnemata

\section{Introduction}

Western Ghats are major diversity hotspot for both flora \& fauna. Plant diversification has been implicated as a major factor affecting the diversity of bugs, beetles \& other insect groups (Farrell 1998). Insect associated fungi \& also their crucial role in nutritional requirement for insect had remained under study (Suh et al. 2005). Due to less studies on insect gut associated fungi, survey was conducted in Western Ghats to isolate fungi. Species of Leptoxyphium causes a kind of sooty mould \& belongs to the family Capnodiaceae. They are found to be restricted to the glandular trichomes of leaves. Leptoxyphium occurs worldwide in form of sooty mould \& frequently in pure colonies (Hughes 1976). Though Leptoxyphium is plant pathogenic fungi, the association is not observed in insects so far. Recently two new species, Leptoxyphium madagascariense (Cheewangkoon et al. 2009) on leaves of Eucalyptus camaldulensis \& L. kurandae (Crous et al. 2011) on leaves of Eucalyptus sp. were described. Literature survey of compilation of Indian fungi shows that so far six species from genus Leptoxyphium are recorded earlier from India which includes L. axillatum (Hughes 1976) on leaves of Albizia lebbeck (L.); L. bahiense (Batista 1963) on leaves of Gossypium barbadense (L.), G. arboretum (L.), G. hirsutum (L.); L. fumago (Srivastava 1982) on leaves of Kydia pinnata (L.), Ilex diopyrena (L.), Alnus nepalensis (L.), Mangifera indica (L.), Quercus leucotrichophora (L.), Coix lycrima-jobi (L.), Rhododendron arboretum (L.); L. graminum Patouillard (Spegazzini 1918) on Citrus sp.; L. longispora (Jain \& Mehta 2004) on leaves of Hibiscus rosa-sinensis (L.) \& Leptoxyphium sp. (Spegazzini 1918) on 
Crescentia pinnata (L.); L. zeae (Mukerji \& Khanna 1983) on leaves of Zea mays (L.) (Mukerji et al 1983, Bilgrami et al 1991, Jain et al. 2004, Jamaluddin et al. 2004). However, L. kurandae is not reported from India. We obtained a culture of Leptoxyphium kurandae from the gut of Dusky Cotton bug (Lygaeidae) which feeds on leaves (Vennila 2007).

\section{Materials \& Methods}

\section{Isolates and morphology}

Bug was collected from leaves directly and transported alive to the laboratory. It was surface disinfected with $95 \%$ ethanol and rinsed in $0.7 \%$ saline solution before removal of the gut and dissected out aseptically. Gut was suspended in $0.7 \%$ saline, homogenized by using pestle which was used as stock. Microbial load was reduced using serial dilution by 10 fold diluting stock solution. One unit of stock was removed and added in next tube containing 9 unit of $0.7 \%$ saline called $1^{\text {st }}$ dilution ie. $10^{-1}$ and dilutions are made up to $10^{-4}$ which were then spread on to the $2 \%$ PDA plates supplemented by antibiotics. Isolated fungal colonies were purified on $2 \%$ PDA plates. Out of these, one was selected for further study on the basis of molecular data. A herbarium specimen was deposited in the Ajrekar Mycological Herbarium (AMH), India (AMH 9616); a culture was deposited at Microbial Culture Collection (MCC), India (MCC 1085) and in Centraalbureau voor Schimmelcultures (CBS), Netherlands (CBS 135836).

For morphotaxonomic studies and photomicrographs, Olympus BX53 microscope (Olympus, Japan) was used fitted with ProgRes C5 camera (Jenoptik, USA). For microscopic examination, fungal colony was mounted on glass slides with lactic acid cotton blue (Hi-Media). Measurements of all taxonomically relevant parameters were made by Jenoptik, USA. Colony characteristics in culture were studied on 5 different media: $2 \%$ malt extract agar (MEA), potato dextrose agar (PDA), 2\% oat meal agar (OA), potato carrot agar (PCA) and Czapek dox agar (CDA). To test optimum temperature for growth, culture plates PDA, CDA, MEA, PCA, 2\% OA were incubated at $5-45 \pm 2^{\circ} \mathrm{C}$ temperatures range.

\section{DNA extraction, PCR and sequencing}

Genomic DNA was isolated from fungal mycelium grown on PDA, using QIAamp® DNA Mini Kit (Qiagen, Inc., Valencia CA) as per manufacturer's instructions and quantified by NanoDrop spectrophotometer (ND-1000, Thermo scientific, USA). Two universal primer pairs ITS1-ITS4 (White et al. 1990) and LR7-5.8S (Vilgalys \& Hester 1990) were used separately for amplification of the internal transcribed spacer (ITS1-5.8S-ITS2) region and D1/D2 region of the large subunit (LSU) rRNA gene respectively by using PE 9700 thermocycler (PE Applied Biosystems, Singapore). The PCR was carried out by standard techniques with the following cycling program: initial denaturation at $94^{\circ} \mathrm{C}$ for $5 \mathrm{~min}, 35$ cycles of denaturation at $94^{\circ} \mathrm{C}$ for 1 min, annealing at $55^{\circ} \mathrm{C}$ for $1 \mathrm{~min}$, extension at $72^{\circ} \mathrm{C}$ for $1 \mathrm{~min}$ and final extension at $72^{\circ} \mathrm{C}$ for 10 min and hold on $20^{\circ} \mathrm{C}$. The purified double-stranded PCR product was used as templates for sequencing with an ABI 3730 xl DNA sequencer using the Big Dye Terminator cycle sequencing kit (Applied Biosystems, Inc., Foster City, CA). The sequence homology was carried by using BLASTn search to compare it with available sequences of Leptoxyphium in GenBank database (Zhang et al. 2000).

Leptoxyphium kurandae Crous \& R.G. Shivas, Persoonia, 26: 145, 2011

Figs $1-2$ MycoBank MB560176

Optimum temperature for growth was $20-25^{\circ} \mathrm{C}$. Mycelium consisting of grey-brown hyphae with 3.6-9.1 $\mu \mathrm{m}$ diam, septate, branched, constricted at septa, forming hyphal ropes, thick-walled, smooth and frequently encased in mucoid sheath. Conidiomata (Fig. 2E) synnematous, separate or in clusters of 2-3, erect, straight to slightly flexuous; bulbous base brown $25.1-39.5 \times 25.6-28.1$ $\mu \mathrm{m} ;(\bar{x}=32.7 \times 26.47 \mu \mathrm{m}, \mathrm{n}=10)$, cylindrical part dark olivaceous brown $23.3-67.7 \times 11.8-23.3$ $\mu \mathrm{m} ;(\bar{x}=44.8 \times 15.5 \mu \mathrm{m}, \mathrm{n}=10)$, and after 3 months (Fig. 2D) $518.1-1278 \times 9.57-12.83 \mu \mathrm{m} ;(\bar{x}$ 
$=840.2 \times 13.3 \mu \mathrm{m}, \mathrm{n}=10)$, hyphal apex 22.3-65.7 $\times 19-68.9 \mu \mathrm{m} ;(\bar{x}=44.2 \times 38.3 \mu \mathrm{m}, \mathrm{n}=10)$, Conidiophores (Fig. 1A-C) subcylindrical to subulate, 0-2-septate, 3.5-29.6 $\times 1.0-3.3 \mu \mathrm{m} ;(\bar{x}=$ $15.8 \times 1.8 \mu \mathrm{m}, \mathrm{n}=15)$, tightly aggregated in apical part of synnemata. Conidiogenous cells intercalary, terminal, phialidic, $1.4-5.1 \times 0.5-2.1 \mu \mathrm{m} ;(\bar{x}=2.4 \times 1.0 \mu \mathrm{m}, \mathrm{n}=10)$, tapering, with parallel to wall and visible collarette. Conidia (Fig. 1D) broadly ellipsoid with rounded ends, 0-1 septate, eguttulate, hyaline, smooth, 4.1-11.7 $\times 1.3-3.9 \mu \mathrm{m} ;(\bar{x}=6.8 \times 2.2 \mu \mathrm{m}, \mathrm{n}=50)$, aggregating at apex of synnemata in drop of liquid (Fig. 1E).

Sexual stage - Not known

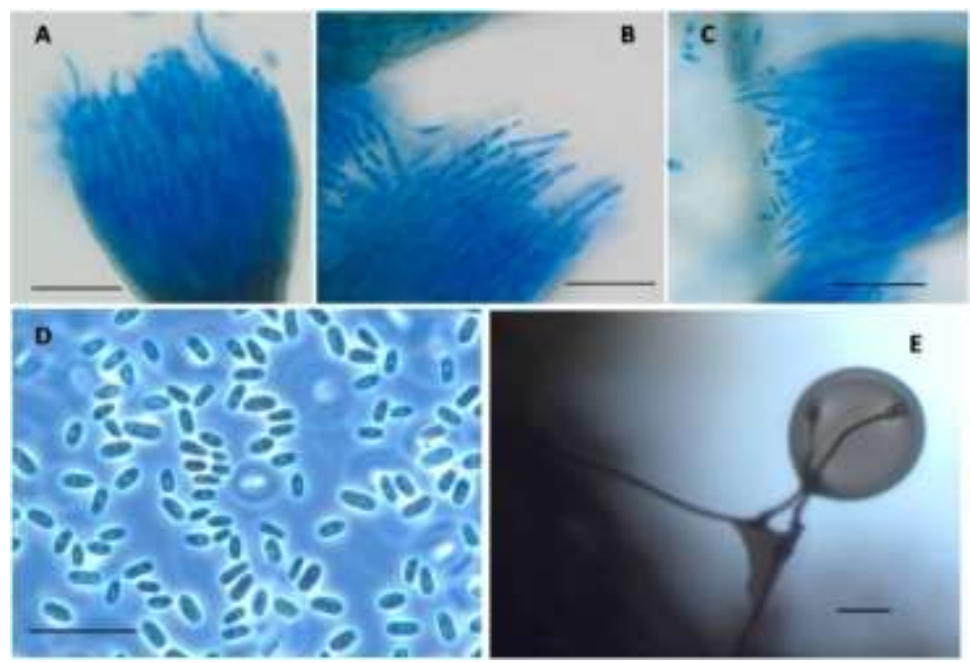

Fig. 1 - Leptoxyphium kurandae MCC 1085. A: apical structure; B-C: conidiophore \& conidiogenous cells; D: conidia; E: conidia produced in drop of liquid at top of synnemata. Bars A-D $20 \mu \mathrm{m} ; \mathbf{E} 100 \mu \mathrm{m}$.

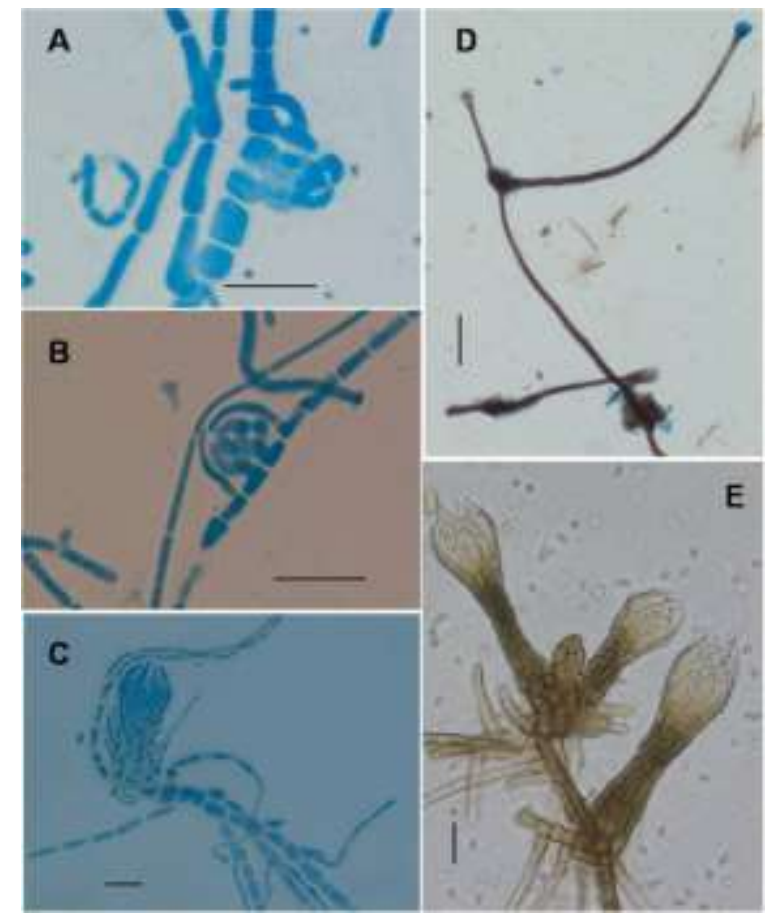

Fig. 2 - Developmental stages of formation of synnematous conidiophores structure of $L$. kurandae MCC 1085 in artificial culture media. Bars A-C, E $20 \mu \mathrm{m} ;$ D $100 \mu \mathrm{m}$. A: Cells differentiation; B: rearrangement of cells; C: formation of synnematous conidiophore structure; D: Complete developed synnematous structure; E: Phase contrast image of synnematous conidiophores with hyphal apices 
Culture characteristics $-\left(25^{\circ} \mathrm{C}\right.$ in dark, after 2 wks $)$ : Colonies were slow growing and spreading, moderate aerial mycelium and even margins, reaching $28 \mathrm{~mm}$ diam after $2 \mathrm{wk}$; on malt extract agar surface olivaceous grey VI' ", ' $i$ (121), outer region isabelline III' $i$ (65), and pale hazel IV "' $i$ (88) in reverse; on oatmeal agar surface olivaceous grey VI", ${ }^{\prime}{ }_{i}$ (121); on potato-dextrose agar surface dark greenish olivaceous IV",'i (90), grey olivaceous V', ${ }^{\prime} i$ (107) in outer region and reverse (Rayner 1970).

Material examined - India, Pune (Western Ghats), Maharashtra, from gut of Dusky Cotton Bug, 10 January 2013, Swapnil Kajale (Holotype, AMH 9616; culture, MCC 1085, CBS 135836). Gene sequences: KF826942 (ITS), KF826943 (LSU)

Notes - The genus Leptoxyphium Speg. typified by Leptoxyphium graminum (Pat.) Speg. mainly characterized by the synnemata arising from helically twisting hyphae or ropes of repent hyphae with terminal conidiogenous zone. Hyphae composed of cylindrical cells \& mucilaginous hyphal outer walls (Hughes 1976). This genus has been expanded to include eighteen legitimate species according to mycobank.

\section{Discussion}

Based on BLASTn search of NCBI's GenBank nucleotide database, the closest hits using the ITS \& LSU sequences of L. kurandae MCC 1085 are showed in Table 1 . The sequences of ITS \& LSU domain confirms the closest species in terms of pairwise sequence similarity (using BLASTn search tool) as L. kurandae (99\% similarity), whereas the L. madagascariense with 98\% similar.

Table 1- NCBI-BLAST hits (ITS \& LSU) against Leptoxyphium kurandae MCC 1085

\begin{tabular}{|c|c|c|c|c|}
\hline ITS & & imilarity (\%) & $\mathbf{L S U}$ & Similarity (\%) \\
\hline \multicolumn{2}{|c|}{ Leptoxyphium kurandae (JF951150) } & 99 & $\begin{array}{l}\text { Leptoxyphium } \\
\text { (JF951170) }\end{array}$ & 99 \\
\hline \multirow{2}{*}{$\begin{array}{l}\text { Leptoxyphium } \\
\text { 2011(HQ631026) } \\
\text { Leptoxyphium } \\
\text { (GQ303277) }\end{array}$} & sp. $\quad$ TMS- & 99 & $\begin{array}{l}\text { Microxyphium } \\
\text { (AY004337) }\end{array}$ & 99 \\
\hline & madagascariense & 98 & $\begin{array}{l}\text { Leptoxyphium } \quad \text { fumago } \\
\text { (GU214430) }\end{array}$ & 99 \\
\hline \multirow{2}{*}{\multicolumn{2}{|c|}{ Polychaeton citri (GU214649) }} & 91 & $\begin{array}{l}\text { Leptoxyphium madagascariense } \\
\text { (GQ303308) }\end{array}$ & 98 \\
\hline & & & $\begin{array}{l}\text { Capnodium } \\
\text { (GU214400) }\end{array}$ & 98 \\
\hline
\end{tabular}

There is variation in morphological characters viz. size of hyphal apex, cylindrical part, conidiogenous cells and also branched synnematous structures showing slight variation in morphological features from $L$. kurandae. Also the present species is very much different than $L$. madagascariense (Table 2), but rDNA sequence comparisons (Table 1) showed that our isolate is indeed L. kurandae with $99 \%$ similarity. As observed morphologically after 3 months, successive proliferated fructifications were seen of which a length of cylindrical part increased drastically high as 518.1-1278 x 9.57-12.83 $\mu \mathrm{m}$ in pure culture. Also in the old culture multiple secondary synnemata arise from single conidiophore of a conidiomata to form a branched structure (Fig. 2D). No reports were found that insect gut is a habitat of Leptoxyphium other than the insect honeydew (sugar rich liquid). The present fungus might have entered in the gut of bug through the leaves on which it was feeding or living. The role of Leptoxyphium is not known in gut of insect whether pathogenic or symbiotic so far but it might be harmful to insect because of some phenolic compounds produced by Leptoxyphium (Singh et al. 2005). Sequencing of rDNA shows that our isolate is Leptoxyphium kurandae, a species not previously recorded from insect gut. Moreover, there is no previous record of L. kurandae from India. The isolate is reported for the first time from gut of Dusky cotton bug which is a common pest on cotton and leaves (Vennila 2007). Therefore, the present fungus is reported as new record from insect gut and also from India. 
Table 2- Comparison of closely identical Leptoxyphium species.

\begin{tabular}{|c|c|c|c|}
\hline Parameters & $\begin{array}{l}\text { L. kurandae MCC } \\
1085\end{array}$ & $\begin{array}{l}\text { L. kurandae CBS } \\
129530\end{array}$ & L. madagascariense CBS 120605 \\
\hline Conidia & $4.1-11.7 \times 1.3-3.9 \mu \mathrm{m}$ & $(4-) 6-7(-9) \times 2-3 \mu \mathrm{m}$ & $4.5-5 \times 3-3.5 \mu \mathrm{m}$ \\
\hline Conidiophore & $3.5-29.6 \times 1.0-3.3 \mu \mathrm{m}$ & $15-25 \times 2-3 \mu \mathrm{m}$ & - \\
\hline Conidiogenous cells & $1.4-5.1 \times 0.5-2.1 \mu \mathrm{m}$ & $7-10 \times 2-2.5 \mu \mathrm{m}$ & $\leq 1 \times 2.8 \mu \mathrm{m}$ \\
\hline Bulbous base & $\begin{array}{l}25.1-39.5 \times 25.6-28.1 \\
\mu \mathrm{m}\end{array}$ & $30-50 \times 25-35 \mu \mathrm{m}$ & - \\
\hline Cylindrical part & $\begin{array}{l}23.3-67.7 \times 11.8-23.3 \\
\mu \mathrm{m}\end{array}$ & $60-100 \times 12-15 \mu \mathrm{m}$ & $\begin{array}{l}(200-) 250(-300) \times(8-) 10-12(-15) \\
\mu \mathrm{m}\end{array}$ \\
\hline Hyphal apex & $22.3-65.7 \times 19-68.9 \mu \mathrm{m}$ & $30-50 \times 25-40 \mu \mathrm{m}$ & $35-50 \times 35-60 \mu \mathrm{m}$ \\
\hline
\end{tabular}

\section{Acknowledgements}

The authors thank Department of Biotechnology (DBT), Government of India \& Microbial Culture Collection Project (BT/PR10054/NDB/52/94/2007) for funding and Director, National Centre for Cell Science, India for providing laboratory facilities.

\section{References}

Batista AC, Ciferri R. 1963 - The sooty-molds of the family Asbolisiaceae. Quaderno del Laboratorio Crittogamico del Instituto Botanico dell’Università di Pavia 31, 1-229.

Bilgrami KS, Jamaluddin, Rizwi MA. 1991 - Fungi of India: List and references. Today \& Tomorrow Printers \& Publishers, New Delhi, India.

Cheewangkoon R, Groenewald JZ, Summerell BA, Hyde KD, To-anun C, Crous PW. 2009 Myrtaceae, a cache of fungal biodiversity. Persoonia 23, 55-85.

Crous PW, Groenewald JZ, Shivas RG. 2011 - Fungal Planet description sheets: 69 - 91. Persoonia 26, 144-145.

Farrell BD. 1998 - 'Inordinate fondness' explained: why are there so many beetles? Science 281, $555-559$.

Hughes SJ. 1976 - Sooty moulds. Mycologia 68, 693-820.

Jain SL, Rai AN, Mehta P. 2004 - Two new anamorphic fungi from Madhya Pradesh. Indian Phytopathology 57, 226-230.

Jamaluddin, Goswami MG, Ojha BM. 2004 - Fungi of India: 1989-2001. Scientific Publishers, Jodhpur, India.

Mukerji KG, Gupta R, Khanna M, Rajeevalochana M. 1983 - Fungi of Delhi XXXI. Some saprophytic fungi. In Fungi of the Indian Subcontinent. A Collection of Papers. Bibliotheca Mycologica 91, 295.

Rayner RW. 1970 - A mycological color chart. Kew Surrey UK: Commonwealth Mycological Institute and British Mycological Society.

Srivastava RC. 1982 - Notes on two interesting fungi from India. Archiv für Protistenkunde 125(1-4), 331-333

Singh DP, Maurya S, Prakash OM, Singh UP. 2005 - Phenolic composition and antifungal activity of culture filtrate of Leptoxyphium axillatum. Indian Phytopathology 58, 143-148.

Spegazzini C. 1918 - Notas micológicas. Physis Revista de la Sociedad Argentina de Ciencias Naturales 4(17), 281-295.

Suh S, McHugh JV, Pollock DD, Blackwell M. 2005 - The beetle gut: a hyper diverse source of novel yeasts. Mycological Research 109, 261-265.

Vennila S, Biradar VK, Sabesh M, Bambawale OM. 2007 - Know Your Cotton Insects Stainers (red and dusky cotton bugs). Crop Protection Folder Series 9 of 11. 
Vilgalys R, Hester M. 1990 - Rapid genetic identification and mapping of enzymatically amplified ribosomal DNA from several Cryptococcus species. Journal of Bacteriology 172, 42394246.

White TJ, Bruns T, Lee S, Taylor JW. 1990 - Amplification and direct sequencing of fungal ribosomal RNA genes for phylogenetics. In: Innis MA, Gelfand DH, Sninsky JJ, White TJ (eds), PCR protocols: a guide to methods and applications. Academic Press, New York, pp 315-322.

Zhang Z, Schwartz S, Wagner L, Miller W. 2000 - A greedy algorithm for aligning DNA sequences. Journal of Computational Biology 7, 203-214 doi: $10.1089 / 10665270050081478$. 